OPEN ACCESS

Edited by:

Zhongchang Wang, Laboratório Ibérico Internacional de Nanotecnologia (INL), Portugal

Reviewed by:

Yong Zhang,

Xiangtan University, China

Qi Qi,

Jilin University, China

*Correspondence:

Qu Zhou

zhouqu@swu.edu.cn

Caisheng Wang

cwang@wayne.edu

Specialty section:

This article was submitted to

Nanoscience,

a section of the journal

Frontiers in Chemistry

Received: 27 August 2018 Accepted: 18 October 2018 Published: 06 November 2018

Citation:

Lu Z, Zhou Q, Wang C, Wei Z, Xu L and Gui $Y$ (2018) Electrospun $\mathrm{ZnO}-\mathrm{SnO}_{2}$ Composite Nanofibers and Enhanced Sensing Properties to $\mathrm{SF}_{6}$ Decomposition Byproduct $\mathrm{H}_{2} \mathrm{~S}$.

Front. Chem. 6:540

doi: 10.3389/fchem.2018.00540

\section{Electrospun $\mathrm{ZnO}-\mathrm{SnO}_{2}$ Composite Nanofibers and Enhanced Sensing Properties to $\mathrm{SF}_{6}$ Decomposition Byproduct $\mathrm{H}_{2} \mathrm{~S}$}

\author{
Zhaorui Lu ${ }^{1}$, Qu Zhou ${ }^{1,2 *}$, Caisheng Wang ${ }^{2 \star}$, Zhijie Wei ${ }^{1}$, Lingna $X u^{1}$ and Yingang Gui ${ }^{1}$ \\ ${ }^{1}$ College of Engineering and Technology, Southwest University, Chongqing, China, ${ }^{2}$ Electrical and Computer \\ Engineering Department, Wayne State University, Detroit, MI, United States
}

Hydrogen sulfide $\left(\mathrm{H}_{2} \mathrm{~S}\right)$ is an important decomposition component of sulfur hexafluoride $\left(\mathrm{SF}_{6}\right)$, which has been extensively used in gas-insulated switchgear (GIS) power equipment as insulating and arc-quenching medium. In this work, electrospun $\mathrm{ZnO}-\mathrm{SnO}_{2}$ composite nanofibers as a promising sensing material for $\mathrm{SF}_{6}$ decomposition component $\mathrm{H}_{2} \mathrm{~S}$ were proposed and prepared. The crystal structure and morphology of the electrospun $\mathrm{ZnO}-\mathrm{SnO}_{2}$ samples were investigated by $\mathrm{X}$-ray diffraction $(\mathrm{XRD})$, scanning electron microscopy (SEM) and transmission electron microscopy (TEM), respectively. The composition of the sensitive materials was analyzed by energy dispersive X-ray spectrometers (EDS) and X-ray photoelectron spectroscopy (XPS). Side heated sensors were fabricated with the electrospun $\mathrm{ZnO}-\mathrm{SnO}_{2}$ nanofibers and the gas sensing behaviors to $\mathrm{H}_{2} \mathrm{~S}$ gas were systematically investigated. The proposed $\mathrm{ZnO}-\mathrm{SnO}_{2}$ composite nanofibers sensor showed lower optimal operating temperature, enhanced sensing response, quick response/recovery time and good long-term stability against $\mathrm{H}_{2} \mathrm{~S}$. The measured optimal operating temperature of the $\mathrm{ZnO}-\mathrm{SnO}_{2}$ nanofibers sensor to $50 \mathrm{ppm} \mathrm{H}_{2} \mathrm{~S}$ gas was about $250^{\circ} \mathrm{C}$ with a response of 66.23 , which was 6 times larger than pure $\mathrm{SnO}_{2}$ nanofibers sensor. The detection limit of the fabricated $\mathrm{ZnO}-\mathrm{SnO}_{2}$ nanofibers sensor toward $\mathrm{H}_{2} \mathrm{~S}$ gas can be as low as $0.5 \mathrm{ppm}$. Finally, a plausible sensing mechanism for the proposed $\mathrm{ZnO}-\mathrm{SnO}_{2}$ composite nanofibers sensor to $\mathrm{H}_{2} \mathrm{~S}$ was also discussed.

Keywords: $\mathrm{ZnO}_{-} \mathrm{SnO}_{2}$ nanofibers, electrospinning, $\mathrm{H}_{2} \mathrm{~S}$, sensing properties, $\mathrm{SF}_{6}$ decomposition components

\section{INTRODUCTION}

Sulfur hexafluoride $\left(\mathrm{SF}_{6}\right)$ insulating gas has excellent insulation performance and arc quenching. It is widely applied in gas-insulated switchgear (GIS) of power system as electrical insulator as well as arc-quenching medium (Beroual and Haddad, 2017; Zhang X. et al., 2017). However, partial discharge and disruptive discharge might occur in GIS equipment during the long run, accounting for the $\mathrm{SF}_{6}$ gas decomposing to various decomposition components, such as $\mathrm{H}_{2} \mathrm{~S}, \mathrm{SO}_{2}, \mathrm{SOF}_{2}, \mathrm{SO}_{2} \mathrm{~F}_{2}$ (Tsai, 2007; Liu et al., 2017). Previous researches have reported that these typical decomposition components are able to accelerate the corrosion rate of the GIS equipment and increase the paralysis possibility of the power system (Zhang X. et al., 2016; Li et al., 2017). Therefore, accurate and effective detection of $\mathrm{SF}_{6}$ gas decomposition components is significant to estimate and optimize the operation state of GIS power equipment. 
Semiconductor metal oxides such as $\mathrm{SnO}_{2}$ (Qi et al., 2014; Li et al., 2016; Shahabuddin et al., 2017; Zhou et al., 2018a), ZnO (Zhou et al., 2013; Zuo et al., 2013; Zhu et al., 2018), $\mathrm{TiO}_{2}$ (Zeng et al., 2012; Park et al., 2017; Zhang Y. X. et al., 2018), NiO (Zhang Y. et al., 2016; Zhou et al., 2018b,c) are the most investigated group for gas sensors owing to their outstanding gas response and selectivity. Sensing nanostructure with high surface area and full electron depletion is advantageous to enhance the sensing performances (Hao et al., 2012; Miller et al., 2014). In particular, the 1D nanostructures such as nanofibers (Jiang et al., 2016), nanorods (Zhang et al., 2014; Zou et al., 2016), and nanotubes (Kong et al., 2015) have been extensively applied to improve gas sensing properties (Li T. M. et al., 2015; Long et al., 2018). Besides, many studies indicated that the selectivity and other important sensing parameters of semiconductor metal oxide nanomaterials can be enhanced by compositing semiconductor metal oxides (Zhou et al., 2015; Tomer and Duhan, 2016; Wang et al., 2017). Jae-Hun Kim et al. systematically investigated the sensing applications of $\mathrm{xSnO}_{2}-(1-\mathrm{x}) \mathrm{Co}_{3} \mathrm{O}_{4}$ composite nanofibers and reported that the $0.5 \mathrm{SnO}_{2}-0.5 \mathrm{Co}_{3} \mathrm{O}_{4}$ sensor exhibited the most outstanding sensing characteristics (Kim et al., 2017). As one of the most important decomposition components of $\mathrm{SF}_{6}$, $\mathrm{H}_{2} \mathrm{~S}$ has been widely studied in the past few years. A variety of composite metal oxides like $\mathrm{Cu}_{2} \mathrm{O}-\mathrm{SnO}_{2}$ (Cui et al., 2013), $\mathrm{CeO}-\mathrm{SnO}_{2}$ (Fang et al., 2000), NiO-ZnO (Qu et al., 2016), and $\mathrm{PdO}-\mathrm{NiO}$ (Balamurugan et al., 2017) have been reported as promising materials for $\mathrm{H}_{2} \mathrm{~S}$ gas sensing applications. However, the report of $\mathrm{ZnO}-\mathrm{SnO}_{2}$ composite nanofibers for $\mathrm{H}_{2} \mathrm{~S}$ gas sensing has been only investigated in a limited number of reports.

In this present work, we have successfully synthesized $\mathrm{ZnO}-\mathrm{SnO}_{2}$ nanofibers by electrospinning method and systematically investigated their sensing performances to $\mathrm{H}_{2} \mathrm{~S}$ gas. The prepared $\mathrm{ZnO}-\mathrm{SnO}_{2}$ nanofibers exhibited significantly improved sensing properties containing high response, low detection limit, low operating temperature and fast response/recovery times to $\mathrm{H}_{2} \mathrm{~S}$ gas detection, which can be ascribed to the large surface area of nanofiber structure and the formation of $n-n$ heterojunctions at interface between $\mathrm{ZnO}$ and $\mathrm{SnO}_{2}$. Finally, a plausible sensing mechanism for the proposed $\mathrm{ZnO}-\mathrm{SnO}_{2}$ composite nanofibers sensor to $\mathrm{H}_{2} \mathrm{~S}$ was also discussed.

\section{EXPERIMENTAL}

\section{Materials Synthesis}

Zinc nitrate hexahydrate $\left(\mathrm{Zn}\left(\mathrm{NO}_{3}\right)_{2} \cdot 6 \mathrm{H}_{2} \mathrm{O}\right)$, stannic chloride pentahydrate $\left(\mathrm{SnCl}_{4} \cdot 5 \mathrm{H}_{2} \mathrm{O}\right), \mathrm{N}, \mathrm{N}$-dimethylformamide (DMF), polyvinylpyrrolidone (PVP, $\mathrm{Mw}=1,300,000)$ and ethanol were of analytical graded and used directly without further purification. All chemicals were purchased from Chongqing Chuandong Chemical Reagent Co., Ltd (Lu et al., 2018).

In the typical synthesis of $\mathrm{ZnO}-\mathrm{SnO}_{2}$ composite nanofibers, $0.7 \mathrm{~g}$ of $\mathrm{SnCl}_{4} \cdot 5 \mathrm{H}_{2} \mathrm{O}$ and $0.6 \mathrm{~g} \mathrm{Zn}\left(\mathrm{NO}_{3}\right)_{2} \cdot 6 \mathrm{H}_{2} \mathrm{O}$ (the molar ratio was 1:1) were dissolved in $5 \mathrm{ml}$ of mixed solvents of ethanol and DMF (The volume ratio was 1:1) and stirred for $2 \mathrm{~h}$. Then $2 \mathrm{~g}$ of PVP was added to the mixture and stirred for $24 \mathrm{~h}$ to form a viscous and homogeneous solution at room temperature. During electrospinning, the obtained mixture was delivered to a glass syringe. A voltage of $25 \mathrm{kV}$ was applied between the flat aluminum foil and syringe at an electrode distance of $15 \mathrm{~cm}$ as shown in Figure 1 and the flow rate is $0.7 \mathrm{ml} / \mathrm{h}$. Finally, the electrospun nanofibers were transferred to a tube furnace and the specimens were annealed at $600^{\circ} \mathrm{C}$ for $3 \mathrm{~h}$ in air for the removal of PVP. For comparison, the pure $\mathrm{SnO}_{2}$ nanofibers were also synthesized without adding $\mathrm{Zn}\left(\mathrm{NO}_{3}\right)_{2} \cdot 6 \mathrm{H}_{2} \mathrm{O}$. The schematic illustration of producing electrospun $\mathrm{ZnO}-\mathrm{SnO}_{2}$ composite nanofibers was shown in Figure 1 (Bai et al., 2018).

\section{Materials Characterization}

To investigate the structures of electrospun $\mathrm{ZnO}-\mathrm{SnO}_{2}$ nanofibers, X-ray diffraction (XRD, D/Max-1200X, Rigaku, Japan) analysis was carried out at room temperature using a Rigaku D/Max-1200X diffractometry with $\mathrm{Cu}-\mathrm{K} \alpha$ radiation $(\lambda$ $=1.542 \AA$ ) over Bragg angles from $20^{\circ}$ to $75^{\circ}$ and the scanning speed of $2 \mathrm{deg} / \mathrm{min}$. The morphologies of the electrospun nanofibers were investigated with a field emission scanning electronic microscopy (FESEM, JSM-6700F, JEOL, Japan) and transmission electron microscopy (TEM, JEM-2100, JEOL, Japan) operated at $120 \mathrm{kV}$. The energy dispersive X-ray spectrum analysis (EDS, Oxford INCA 250, JEOL, Japan) and $\mathrm{X}$-ray photoelectron spectroscopy analysis (XPS, KRATOS X SAM800, Kratos, Kingdom) were tested to analyze the elemental compositions of the sample (Lu et al., 2018).

\section{Gas Sensor Measurements}

Gas sensors were fabricated with a side heated structure as shown in Figure 2A and a theoretic diagram of the test circuit was showed in Figure 2B. As shown in Figure 2A, there are two gold electrodes connected with platinum wire at both ends of the ceramic tube. Firstly, the as-prepared powder was mixed with appropriate amount of anhydrous ethanol and deionized water to form a homogeneous paste (Xu et al., 2015). Then the obtained paste was coated onto a prefabricated ceramic tube to form the sensing film and dried at room temperature for $2 \mathrm{~h}$. Next a $\mathrm{Ni}-\mathrm{Cr}$ heating wire was inserted into the ceramic tube to finish the side heated $\mathrm{H}_{2} \mathrm{~S}$ gas sensor. Finally, the stability of the sensing materials was improved by putting the sensor on the aging instrument of the side heated sensor at $120^{\circ} \mathrm{C}$ for 10 days. The sensor response was defined as $S=R_{a} / R_{g}$ (Zhang Q. Y. et al., 2017), where $R_{a}$ and $R_{g}$ were the resistances of the sensing material measured in air and in atmosphere containing target test gas $\mathrm{H}_{2} \mathrm{~S}$, respectively (Zhu et al., 2017). Gas sensing properties of the obtained sensors were performed with the CGS- 8 TP intelligent gas sensing analysis system (Chemical gas sensor-8, Beijing Elite Tech Co., Ltd., China). The response time was defined as the time required by the sensor to reach $90 \%$ of the final stable resistance when target gas in. The recovery time is the time required to return to $90 \%$ of its original baseline resistance when the sensor was exposed in air again (Nan et al., 2017). The sensing measurement were tested under laboratory condition with room temperature $25^{\circ} \mathrm{C}$ and constant humidity $(50 \%$ relative humidity). 


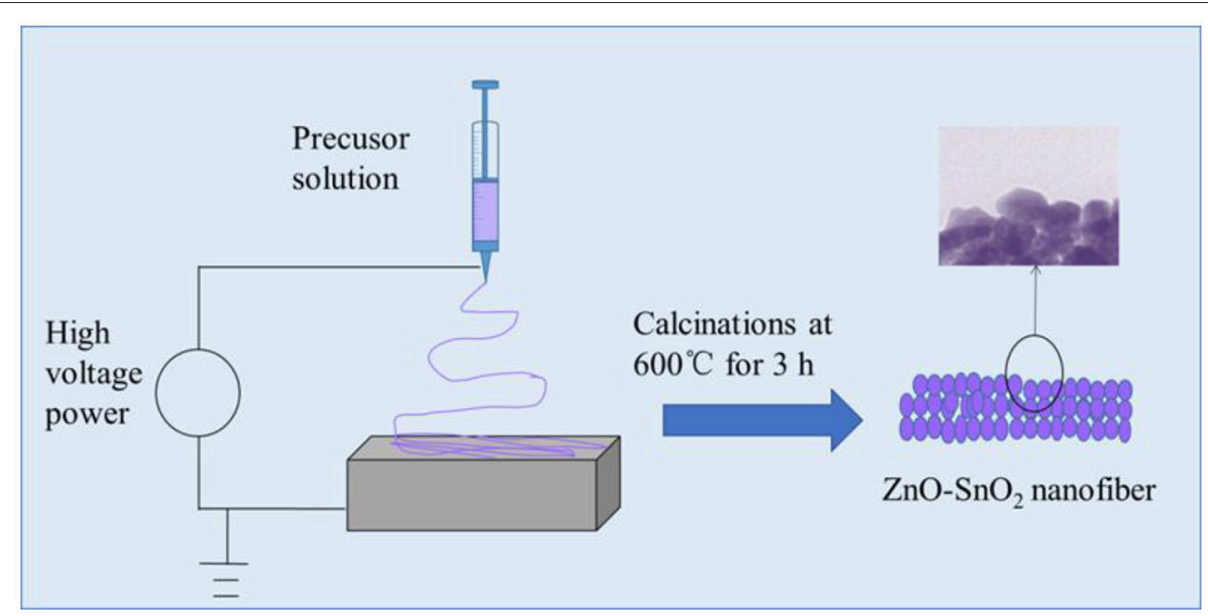

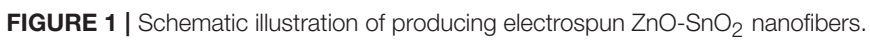
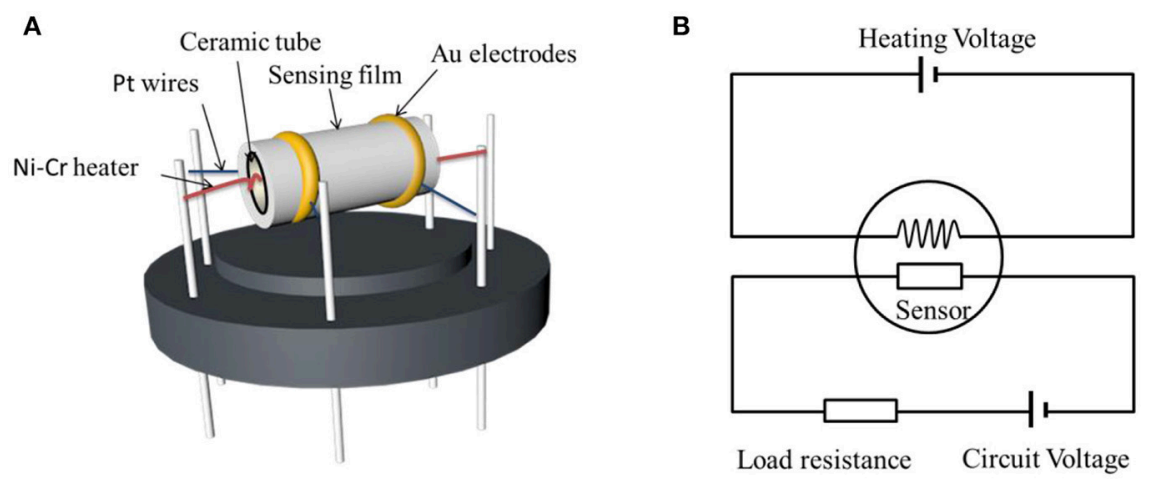

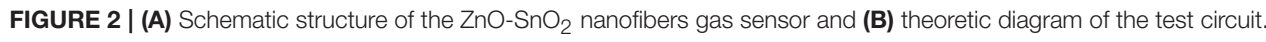

\section{RESULTS AND DISCUSSION}

\section{Morphology and Structure}

Figure 3 shows the XRD pattern of the electrospun $\mathrm{ZnO}-\mathrm{SnO}_{2}$ composite nanofibers. It can be seen from Figure 3 that the XRD peaks are in accordance with the hexagonal wurtzite $\mathrm{ZnO}$ and tetragonal rutile $\mathrm{SnO}_{2}$, compared with the standard pattern of JCPDS card No. 36-1451 and No. 41-1445, respectively. There is neither apparent peak shift nor any other phase corresponding $\mathrm{SnO}, \mathrm{ZnSnO}_{3}$ and $\mathrm{Zn}_{2} \mathrm{SnO}_{4}$, confirming that there are only $\mathrm{SnO}_{2}$ and $\mathrm{ZnO}$ co-exist in the prepared material. The result shows a possibility of developing $n-n$ heterojunction at the interface between $\mathrm{ZnO}$ and $\mathrm{SnO}_{2}$ nanomaterial (Bai et al., 2018). The crystallite sizes of nanoparticels were calculated using Scherrer's equation ( $\mathrm{D}=\mathrm{k} \lambda / \beta \cos \theta$ ) (Lu et al., 2018), and the average crystallite sizes of nanofibers were calculated by diffraction peaks (100), (101) for $\mathrm{ZnO}$, and (110), (101), (221) for $\mathrm{SnO}_{2}$. After calculation, the average crystallite size of $\mathrm{ZnO}$ is $20.1 \mathrm{~nm}$, while it is $19.8 \mathrm{~nm}$ of $\mathrm{SnO}_{2}$.

Figure 4 presents the FESEM and TEM images of the as-prepared $\mathrm{ZnO}-\mathrm{SnO}_{2}$ nanofibers after annealing. Figure 4a

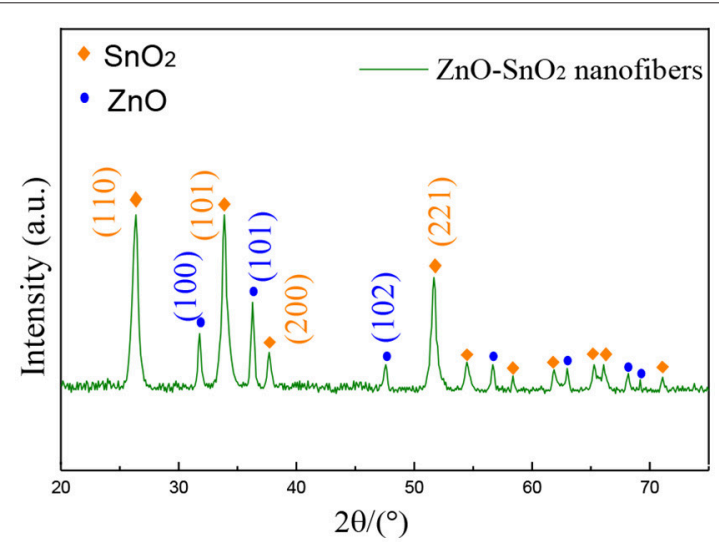

FIGURE 3 | XRD pattern of $\mathrm{ZnO}-\mathrm{SnO}_{2}$ nanofibers sensing material.

consists of randomly oriented nanofibers with diameters of $80-150 \mathrm{~nm}$ and lengths of $0.5-2 \mu \mathrm{m}$. Besides, the $\mathrm{ZnO}^{-\mathrm{SnO}_{2}}$ nanofibers consist of nanoparticles and surface of nanofibers 


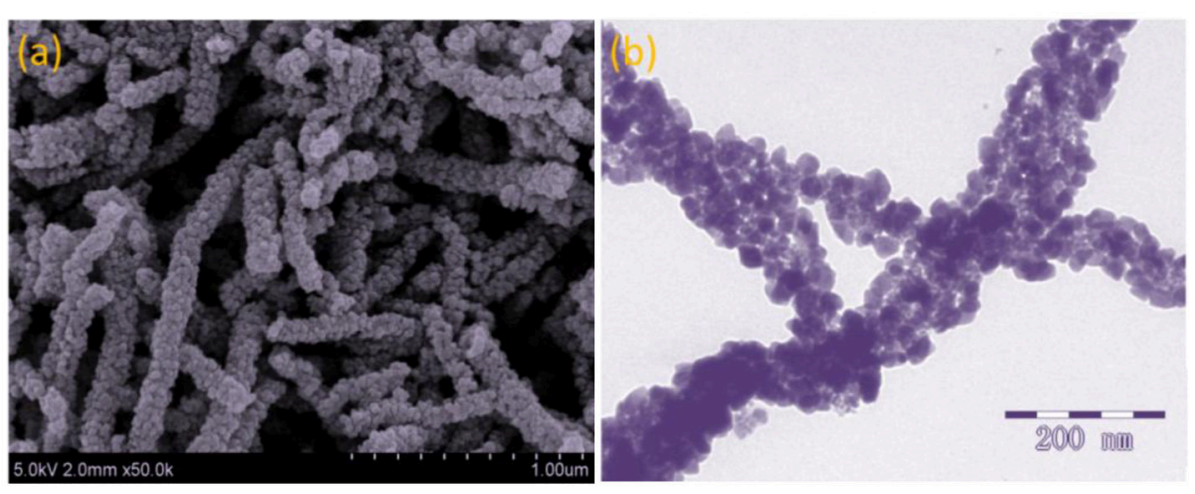

FIGURE 4 | (a) FESEM image and (b) TEM image of electrospun $\mathrm{ZnO}^{-S n O} \mathrm{O}_{2}$ nanofibers.

is rough, which can be attributed to thermal decomposition of PVP caused by annealing. More structural information of the $\mathrm{ZnO}-\mathrm{SnO}_{2}$ nanofibers is researched by TEM characterization as shown in Figure $\mathbf{4 b}$, the single fiber is composed of grain-like nanoparticles with around $20 \mathrm{~nm}$ in size.

Figure 5 demonstrates the EDS spectrum of the electrospun $\mathrm{ZnO}-\mathrm{SnO}_{2}$ nanofibers. It can be seen that the $\mathrm{ZnO}-\mathrm{SnO}_{2}$ composite nanofibers are composed of $\mathrm{Zn}, \mathrm{Sn}$, and $\mathrm{O}$ elements and the atomic ratio of $\mathrm{Zn}$ and $\mathrm{Sn}$ is about 19.63:20.76.

To further analyze the compositions and element valences of the $\mathrm{ZnO}-\mathrm{SnO}_{2}$ nanofibers, XPS tests were investigated. Figure 6A shows the full range XPS survey spectra of the sample. It confirms the presence of $\mathrm{Zn}, \mathrm{O}$, Sn from prepared nanomaterial and $\mathrm{C}$ element which is due to the carbon contamination. The binding energies were calibrated using $\mathrm{C} 1 \mathrm{~s}$ hydrocarbon peak at $284.54 \mathrm{eV}$. Figures 6B,C demonstrate the high resolution spectra of the $\mathrm{Zn} 2 \mathrm{p}$ and Sn $3 \mathrm{~d}$ energy state, respectively. The $\mathrm{Zn} 2 \mathrm{p}$ XPS spectrum (Figure 6B) presents the doublet peaks located at binding energies of $1045.6 \mathrm{eV}$ and $1022.6 \mathrm{eV}$, which corresponds to $\mathrm{Zn} 2 \mathrm{p}_{1 / 2}$ and $\mathrm{Zn} 2 \mathrm{p}_{3 / 2}$, respectively (Li W. Q. et al., 2015). The result indicates that the $\mathrm{Zn}^{2+}$ is the dominant species in the prepared material and in good agreement with the reported data for $\mathrm{ZnO}$ (Zhao et al., 2015). Figure 6C shows the binding energy of $\mathrm{Sn} 3 \mathrm{~d}_{5 / 2}, \mathrm{Sn} 3 \mathrm{~d}_{3 / 2}$ are $487.6 \mathrm{eV}$ and $496.1 \mathrm{eV}$ respectively, which are assigned to the highest oxidation state of $\mathrm{Sn}^{4+}$ for $\mathrm{SnO}_{2}$ (Hamrouni et al., 2014; Chen et al., 2018). It further confirmed that $\mathrm{ZnO}$ and $\mathrm{SnO}_{2}$ coexist in the samples.

\section{Gas-Sensing Properties}

The gas sensor responses of pure $\mathrm{SnO}_{2}$ and $\mathrm{ZnO}-\mathrm{SnO}_{2}$ nanofibers sensors as a function of temperatures in the range of $100-375^{\circ} \mathrm{C}$ toward $50 \mathrm{ppm}$ of $\mathrm{H}_{2} \mathrm{~S}$ gas were tested and shown in Figure 7. The sensing responses of all the prepared sensors increase with increasing temperature and attain a maximum value at 300 and $250^{\circ} \mathrm{C}$ for pure $\mathrm{SnO}_{2}$ and $\mathrm{ZnO}-\mathrm{SnO}_{2}$ nanofibers sensor, respectively. With further increase in temperature, the sensing responses begin to decrease because desorption of $\mathrm{H}_{2} \mathrm{~S}$ is dominated and the amount of the adsorbed gas onto the surface decreases (Zhang et al., 2018). The response of gas sensor based on $\mathrm{ZnO}-\mathrm{SnO}_{2}$ nanofibers for $50 \mathrm{ppm} \mathrm{H}_{2} \mathrm{~S}$ gas at operating

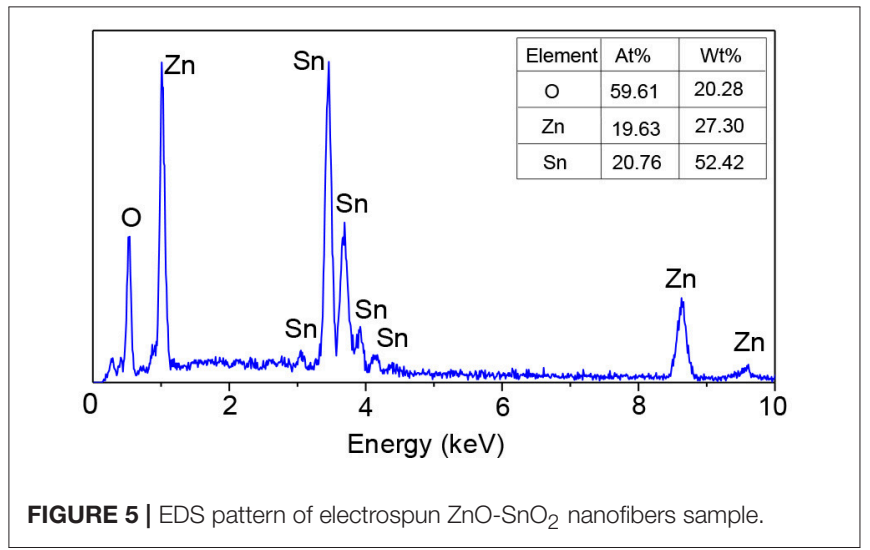

temperature of $250^{\circ} \mathrm{C}$ is 66.23 , while it is 10.49 and $300^{\circ} \mathrm{C}$ for the pure $\mathrm{SnO}_{2}$ nanofibers based sensor. The results indicate that $\mathrm{ZnO}-\mathrm{SnO}_{2}$ composite nanofibers can obviously improve the response to $\mathrm{H}_{2} \mathrm{~S}$ at different working temperatures and reduce the optimal operating temperature.

Figure 8 shows the $\mathrm{H}_{2} \mathrm{~S}$ gas responses of pure $\mathrm{SnO}_{2}$ and $\mathrm{ZnO}-\mathrm{SnO}_{2}$ nanofibers based sensors to different concentration of $\mathrm{H}_{2} \mathrm{~S}$ in the range of $0.5-100 \mathrm{ppm}$ at their optimal operating temperatures measured above. The measured results show that gas responses of the as-prepared gas sensors increase in a good linear relationship from 0.5 to $100 \mathrm{ppm}$. The linear relationship of the response and gas concentration satisfies linear equation $y$ $=1.1003 \mathrm{x}+6.90664$ for electrospun $\mathrm{ZnO}-\mathrm{SnO}_{2}$ nanofibers gas sensor. The higher response of $\mathrm{ZnO}-\mathrm{SnO}_{2}$ nanofibers can be explained by the formation of $n-n$ heterojunctions at the interface between $\mathrm{ZnO}$ and $\mathrm{SnO}_{2}$. Moreover, the sensor detection limit was defined as the target gas concentration value at which the response is above 3 . The response of the $\mathrm{ZnO}-\mathrm{SnO}_{2}$ nanofibers sensor to $0.5 \mathrm{ppm} \mathrm{H}_{2} \mathrm{~S}$ gas can reach up to 3.45 , indicating that the detection limit of the sensor for detecting $\mathrm{H}_{2} \mathrm{~S}$ gas is as low as sub-ppm level.

The dynamic response and recovery curve of the $\mathrm{ZnO}-\mathrm{SnO}_{2}$ nanofibers sensor for $1,5,30$, and $50 \mathrm{ppm}_{2} \mathrm{~S}$ gas was performed and shown in Figure 9. The obtained sensing response values 

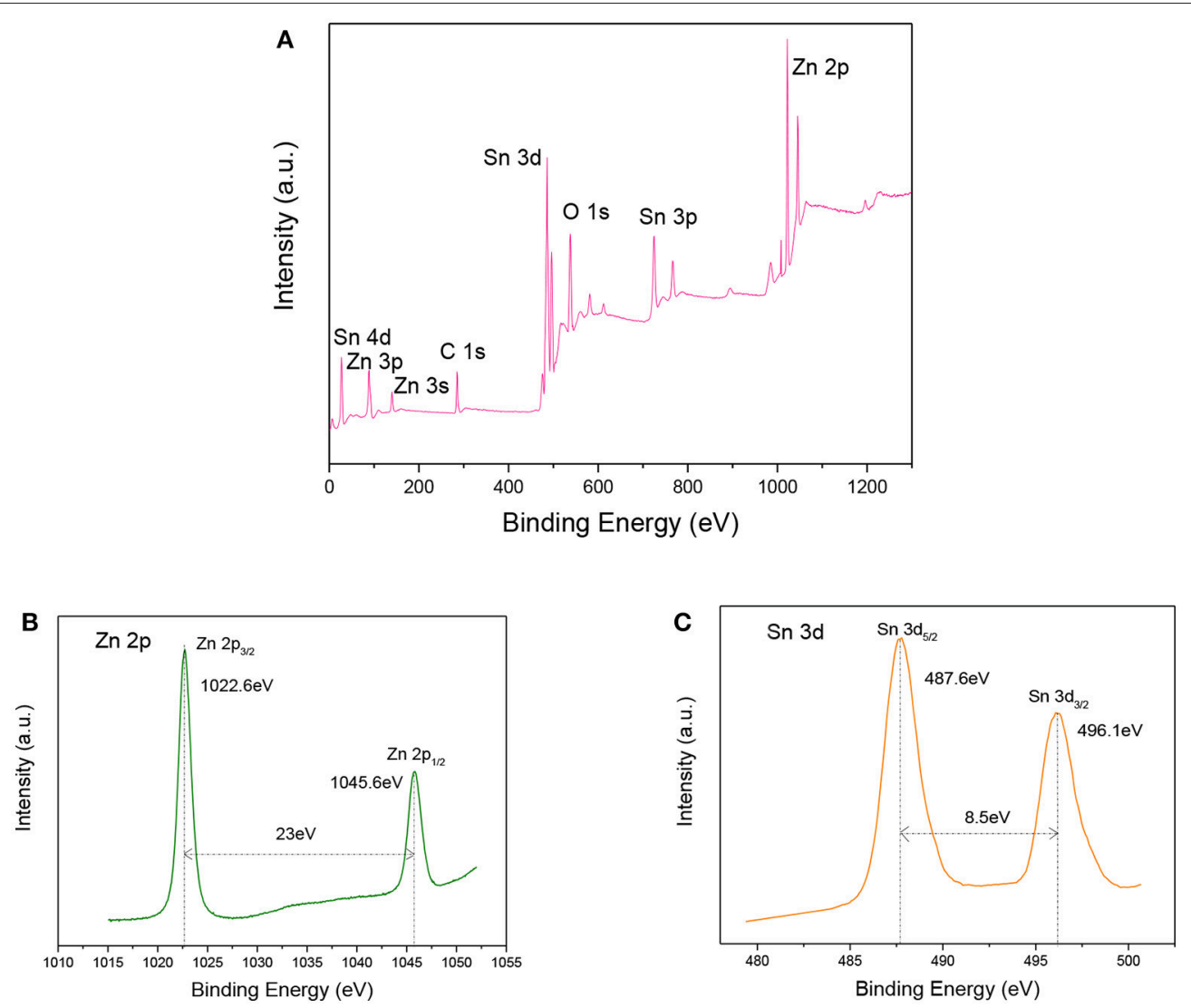

FIGURE 6 | (A) Survey, (B) Zn 2p, (C) $\mathrm{Sn} 3 \mathrm{~d}$ XPS spectra of electrospun $\mathrm{ZnO}-\mathrm{SnO}_{2}$ nanofibers.

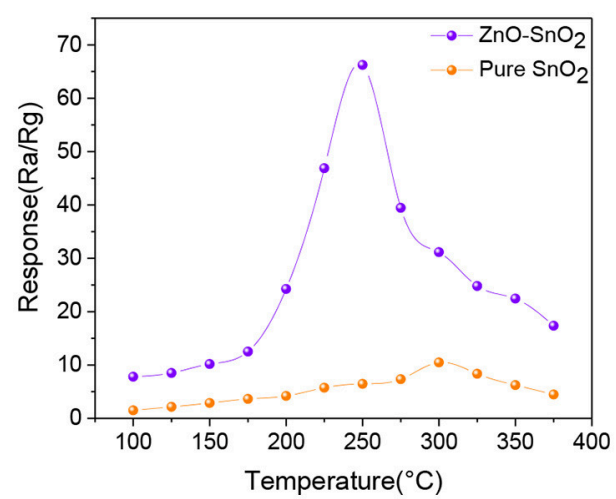

FIGURE 7 | Response to $50 \mathrm{ppm} \mathrm{H}_{2} \mathrm{~S}$ at different operating temperature of $\mathrm{SnO}_{2}$ and $\mathrm{ZnO}-\mathrm{SnO}_{2}$ nanofibers sensors.

are about 7.25, 13.37, 40.31, and 66.23, respectively. The $\mathrm{ZnO}$ $\mathrm{SnO}_{2}$ nanofibers sensor responds rapidly and could recover to its initial value when it was exposed to air again, implying a satisfying stability and reproducibility of the proposed $\mathrm{H}_{2} \mathrm{~S}$ gas sensor.

Figures 10A,B illustrate the response-recovery curve of electrospun $\mathrm{ZnO}-\mathrm{SnO}_{2}$ nanofibers sensor and pure $\mathrm{SnO}_{2}$

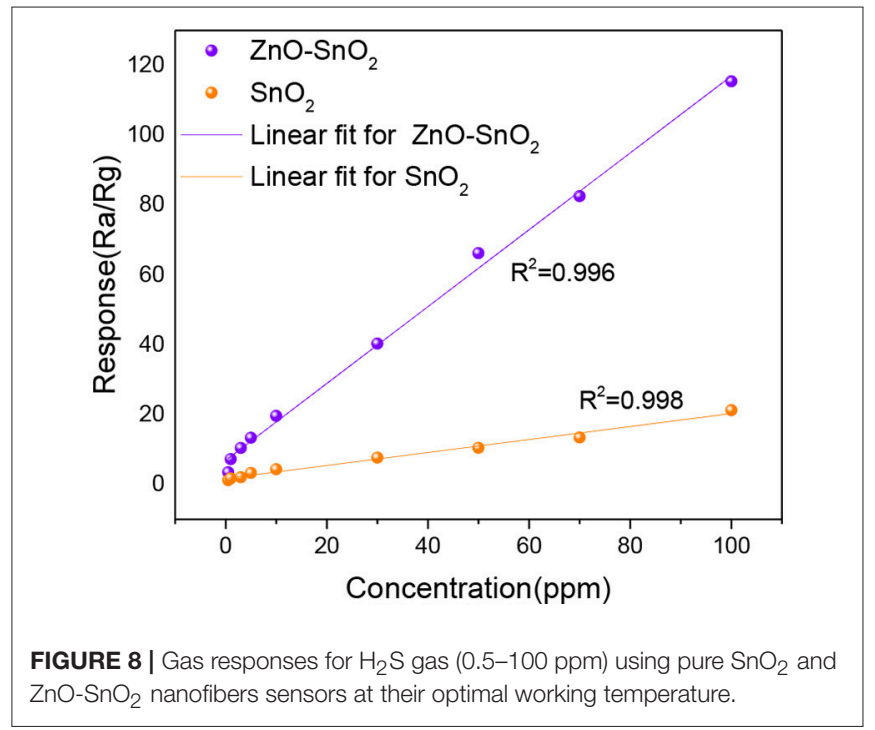

nanofibers sensor to $50 \mathrm{ppm}$ of $\mathrm{H}_{2} \mathrm{~S}$ gas at their optimal operating temperature mentioned above. From the curves, it is observed that the response and recovery time of the $\mathrm{ZnO}-\mathrm{SnO}_{2}$ nanofibers sensor is about 18 and $32 \mathrm{~s}$, respectively, whereas for pure 


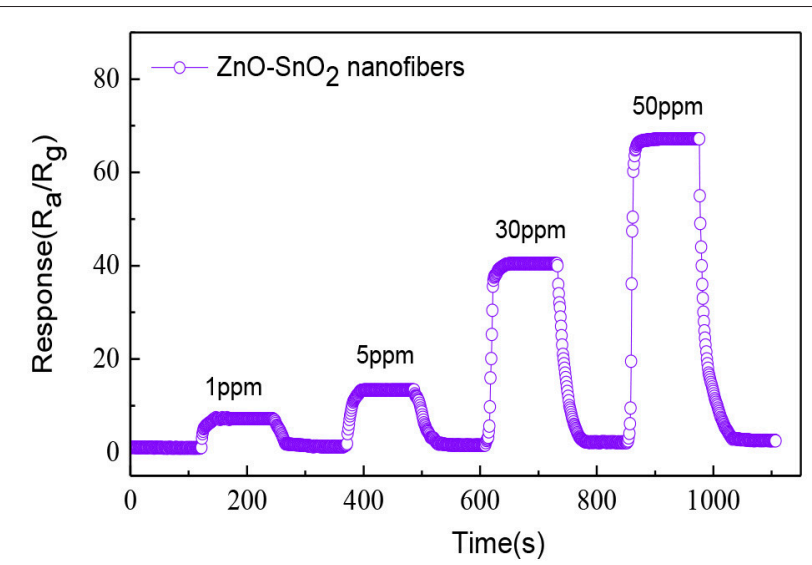

FIGURE 9 | Dynamic response-recovery curve of the sensor based upon $\mathrm{ZnO}-\mathrm{SnO}_{2}$ nanofibers at $250^{\circ} \mathrm{C}$.

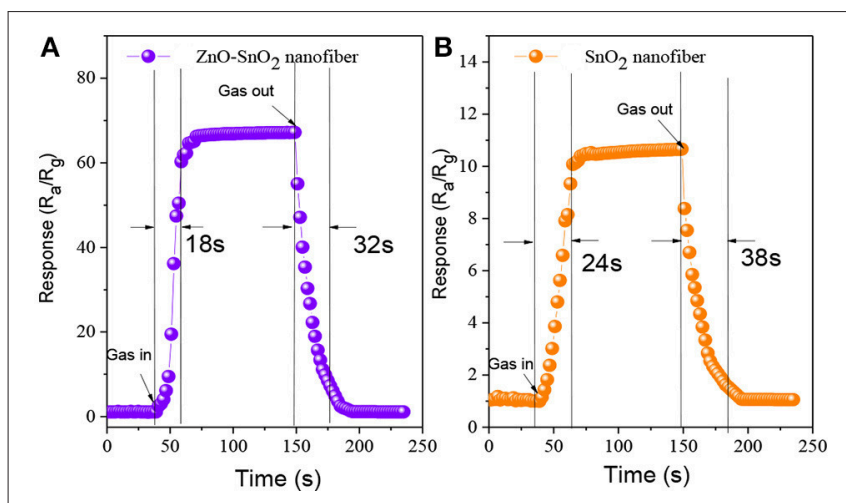

FIGURE 10 | Response-recovery curve of the sensor bases on (A) $\mathrm{ZnO}^{-\mathrm{SnO}_{2}}$ nanofibers (B) pure $\mathrm{SnO}_{2}$ nanofibers.

$\mathrm{SnO}_{2}$ nanofibers sensor the corresponding values is 24 and $38 \mathrm{~s}$, respectively.

Finally, the long-term stability of the fabricated $\mathrm{ZnO}-\mathrm{SnO}_{2}$ nanofibers sensor was measured to $10,30,50$, and $100 \mathrm{ppm}_{2} \mathrm{~S}$ gas at $250^{\circ} \mathrm{C}$ for 30 days as shown in Figure 11. The measured results show that the response has little change for 30 days and confirm a good stability of the fabricated electrospun $\mathrm{ZnO}-\mathrm{SnO}_{2}$ nanofibers sensor.

Experimental results of $\mathrm{ZnO}-\mathrm{SnO}_{2}$ nanofibers sensor have been compared with the results reported by the other workers on $\mathrm{H}_{2} \mathrm{~S}$ sensors and presented in Table 1. It can be seen that electrospun $\mathrm{ZnO}-\mathrm{SnO}_{2}$ nanofibers sensor toward $\mathrm{H}_{2} \mathrm{~S}$ can reach a relatively higher response at lower temperature and the response time is relatively shorter than other sensors reported previously. The obtained results indicate that the electrospun $\mathrm{ZnO}-\mathrm{SnO}_{2}$ nanofibers sensor is promising for $\mathrm{H}_{2} \mathrm{~S}$ gas sensing.

\section{Sensing Mechanism}

$\mathrm{ZnO}$ and $\mathrm{SnO}_{2}$ belong to typical n-type semiconductors, characterized by their high free carrier concentration (Hong

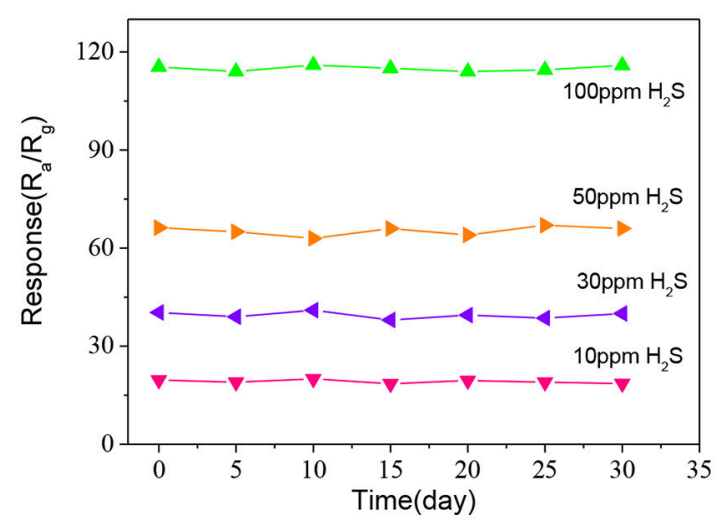

FIGURE 11 | Long term stability property of $\mathrm{ZnO}-\mathrm{SnO}_{2}$ nanofibers sensor.

et al., 2017; Zhou et al., 2018d). The gas sensing mechanism of $\mathrm{ZnO}-\mathrm{SnO}_{2}$ nanofibers is shown in Figure 12. Due to the sensing mechanism of $\mathrm{ZnO}-\mathrm{SnO}_{2}$ sensor follows the surface controlled type, the gas sensing properties are ascribed to the change of the surface resistance, which controlled by the adsorption and desorption of oxygen on the surface of sensing materials (Wei et al., 2014). When $\mathrm{ZnO}-\mathrm{SnO}_{2}$ nanofibers sensor is exposed to air (Figure 12A), the resistance of gas sensor depends on the amount of chemisorbed oxygen species $\left(\mathrm{O}^{-}, \mathrm{O}_{2}^{-}\right.$, and $\left.\mathrm{O}^{2-}\right)$. The free oxygen molecules are absorbed on the surface and capture electrons from the conduction band of the $\mathrm{ZnO}-\mathrm{SnO}_{2}$ nanofibers, which causes a depletion layer around the surface and the increasing the resistance (Cheng et al., 2014). When $\mathrm{ZnO}-\mathrm{SnO}_{2}$ nanofibers sensing materials are exposed to $\mathrm{H}_{2} \mathrm{~S}$ (Figure 12B), the target gas reacts with the adsorbed oxygen and then releases the captured electrons into the conduction band of $\mathrm{ZnO}-\mathrm{SnO}_{2}$ nanifibers to reduce the depletion layer and decrease the resistance.

It is well-known that the chemisorbed oxygen depends on the specific surface area of sensing materials and the operating temperature. $\mathrm{ZnO}-\mathrm{SnO}_{2}$ nanofibers show a big surface area as shown in Figure 4. It means that adsorption capability of $\mathrm{ZnO}$ $\mathrm{SnO}_{2}$ nanofibers was greatly enhanced (Zhang W. et al., 2017). Moreover, $\mathrm{O}^{2-}$ and $\mathrm{O}^{-}$species are regarded as the most oxygen adsorption species at $250^{\circ} \mathrm{C}$, and the following $\mathrm{H}_{2} \mathrm{~S}$ sensing reaction can be considered (Kolhe et al., 2017).

$$
\begin{gathered}
\mathrm{H}_{2} \mathrm{~S}+3 \mathrm{O}^{-} \rightarrow \mathrm{SO}_{2}+\mathrm{H}_{2} \mathrm{O}+3 \mathrm{e}^{-} \\
\mathrm{H}_{2} \mathrm{~S}+3 \mathrm{O}^{2-} \rightarrow \mathrm{SO}_{2}+\mathrm{H}_{2} \mathrm{O}+6 \mathrm{e}^{-}
\end{gathered}
$$

In accordance with the definition about gas response $(\mathrm{S}=$ $\mathrm{R}_{\mathrm{a}} / \mathrm{R}_{\mathrm{g}}$ ), the increasing of $\mathrm{R}_{\mathrm{a}}$ and decreasing of $\mathrm{R}_{\mathrm{g}}$ cause that the response of $\mathrm{ZnO}-\mathrm{SnO}_{2}$ nanofibers is significantly enhanced. Additional electron consumption will occur at the boundaries of $\mathrm{ZnO}$ and $\mathrm{SnO}_{2}$, which further enhances the gas response. The contact of $\mathrm{ZnO}$ and $\mathrm{SnO}_{2}$ provides condition for electrons transfer from $\mathrm{SnO}_{2}$ to $\mathrm{ZnO}$, which has a higher work function of $5.2 \mathrm{eV}$ compared to $\mathrm{SnO}_{2}(4.9 \mathrm{eV})$. It results in the formation 
TABLE 1 | Summary of the $\mathrm{H}_{2} \mathrm{~S}$ gas sensing performances of different gas sensor materials.

\begin{tabular}{|c|c|c|c|c|c|}
\hline Sensor & $\mathrm{H}_{2} \mathrm{~S}$ (ppm) & Temp. $\left({ }^{\circ} \mathrm{C}\right)$ & Response $\left(\mathbf{R}_{\mathbf{a}} / \mathbf{R}_{\mathbf{g}}\right)$ & $\tau_{\text {res }}$ and $\tau_{\text {rec }}$ & References \\
\hline $\mathrm{Zn}_{2} \mathrm{SnO}_{4}$ hollow octahedra & 50 & 260 & 46 & 10 and $25 \mathrm{~s}$ & Ma et al., 2012 \\
\hline$V$ doped $\ln _{2} \mathrm{O}_{3}$ & 50 & 90 & 14 & 15 and $18 s$ & Liu et al., 2014 \\
\hline Al-ZnO thin film & 600 & 200 & 30 & 90 and $209 \mathrm{~s}$ & Kolhe et al., 2018 \\
\hline CuO-functionalized $\mathrm{WO}_{3}$ nanowires & 100 & 300 & 79.8 & $\sim 30$ and $20 \mathrm{~s}$ & Park et al., 2014 \\
\hline micro/nanostructured $\ln _{2} \mathrm{O}_{3}$ porous thin & 50 & 300 & 30 & 16 and $30 \mathrm{~s}$ & Wang et al., 2016 \\
\hline Gold functionalized $\mathrm{MoO}_{3}$ nano flake & 15 & 400 & 260 & 60 and $480 \mathrm{~s}$ & $\begin{array}{l}\text { Munasinghe Arachchige et al., } \\
2018\end{array}$ \\
\hline $\mathrm{ZnO}-\mathrm{SnO}_{2}$ nanofibers & 50 & 250 & 66.23 & 18 and $32 \mathrm{~s}$ & This work \\
\hline
\end{tabular}

Temp., the optimal working temperature. $\tau_{\text {res }}$ and $\tau_{\text {rec }}$ - response time and recovery time.
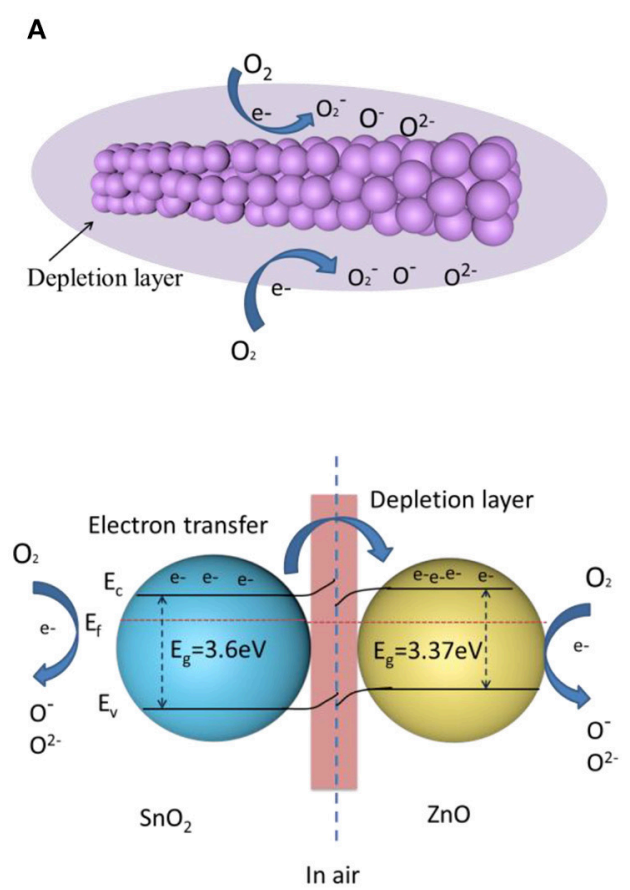

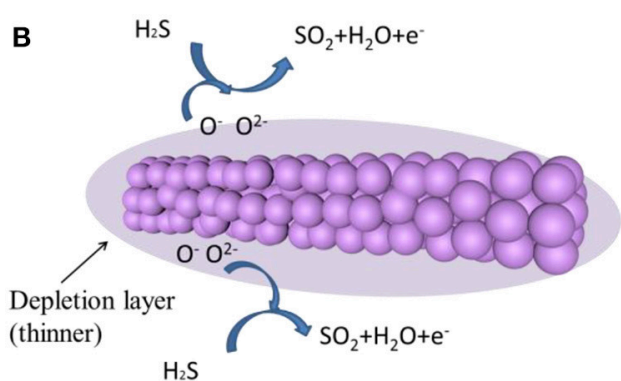

$\mathrm{H}_{2} \mathrm{~S}$

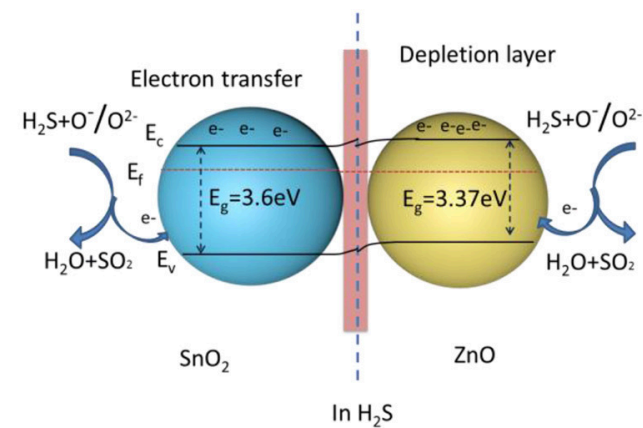

FIGURE 12 | A schematic of the $\mathrm{H}_{2} \mathrm{~S}$ sensing mechanism of the $\mathrm{ZnO}-\mathrm{SnO}_{2}$ nanofibers $\mathbf{( A )}$ when the gas sensor is exposed in air (B) when the gas sensor is exposed in $\mathrm{H}_{2} \mathrm{~S}$ ( $\mathrm{E}_{\mathrm{f}}$ is Fermi level; $\mathrm{E}_{\mathrm{C}}$ is conduction band; $\mathrm{E}_{\mathrm{V}}$ is valence band; $\mathrm{E}_{\mathrm{g}}$ is band gaps).

of an additional depletion layer in the vicinity region between the $\mathrm{ZnO}$ and $\mathrm{SnO}_{2}$, eventually generating a potential barrier for electron flow (Choi et al., 2013). The boundary barrier may decrease when the gas sensor is exposed in $\mathrm{H}_{2} \mathrm{~S}$. More electrons of oxygen species transfer to the sensing material by reaction of $\mathrm{H}_{2} \mathrm{~S}$ with oxygen species, which results the resistance of the sensing material decreases and the response of the sensor increases. However, pure $\mathrm{SnO}_{2}$ does not provide reaction interface, leading to lower gas response. So the $\mathrm{ZnO}-\mathrm{SnO}_{2}$ composite nanofibers exhibit better sensing properties than the $\mathrm{SnO}_{2}$ nanofibers.

\section{CONCLUSIONS}

In summary, $\mathrm{ZnO}-\mathrm{SnO}_{2}$ composite nanofibers were successfully synthesized by electrospinning method and characterized by various techniques. $\mathrm{H}_{2} \mathrm{~S}$ sensing properties of the electrospun nanofibers sensor were also investigated. Compared to the pure $\mathrm{SnO}_{2}$ nanofiber sensor, the $\mathrm{ZnO}-\mathrm{SnO}_{2}$ composite nanofibers sensor shows excellent gas sensing response for $\mathrm{H}_{2} \mathrm{~S}$ gas, which is attributed to the large specific surface and the heterojunctions between $\mathrm{SnO}_{2}$ and $\mathrm{ZnO}$. The proposed $\mathrm{ZnO}-\mathrm{SnO}_{2}$ composite 
nanofibers sensor exhibits good linear relationship between sensing response and gas concentration in the range of $0.5 \sim 100$ ppm and its detection limit is as low as sub-ppm level. Moreover, the proposed sensor achieves good repeatability and longterm stability, making it a promising candidate for detecting $\mathrm{H}_{2} \mathrm{~S}$ gas.

\section{AUTHOR CONTRIBUTIONS}

$\mathrm{ZL}$ and $\mathrm{ZW}$ performed the experiments and analyzed the data with the help from LX and YG. ZL, QZ, and CW wrote and

\section{REFERENCES}

Bai, S. L., Fu, H., Zhao, Y. Y., Tian, K., Luo, R. X., Li, D. Q., et al. (2018). On the construction of hollow nanofibers of $\mathrm{ZnO}-\mathrm{SnO}_{2}$ heterojunctions to enhance the $\mathrm{NO}_{2}$ sensing properties. Sensor. Actuat. B Chem. 266, 692-702. doi: $10.1016 /$ j.snb.2018.03.055

Balamurugan, C., Jeong, Y. J., and Lee, D. W. (2017). Enhanced $\mathrm{H}_{2} \mathrm{~S}$ sensing performance of a p-type semiconducting $\mathrm{PdO}-\mathrm{NiO}$ nanoscale heteromixture. Appl. Surf. Sci. 420, 638-650. doi: 10.1016/j.apsusc.2017. 05.166

Beroual, A., and Haddad, A. (2017). Recent advances in the quest for a new insulation gas with a low impact on the environment to replace sulfur hexafluoride $\left(\mathrm{SF}_{6}\right)$ gas in high-voltage power network applications. Energies 10:1216. doi: 10.3390/en10081216

Chen, Y., Qin, H., and $\mathrm{Hu}$, J. (2018). CO sensing properties and mechanism of Pd doped $\mathrm{SnO}_{2}$ thick-films. Appl. Surf. Sci. 428, 207-217. doi: 10.1016/j.apsusc.2017.08.205

Cheng, L., Ma, S. Y., Li, X. B., Luo, J., Li, W. Q., Li, F. M., et al. (2014). Highly sensitive acetone sensors based on Y-doped $\mathrm{SnO}_{2}$ prismatic hollow nanofibers synthesized by electrospinning. Sensor. Actuat. B-Chem. 200, 181-190. doi: 10.1016/j.snb.2014.04.063

Choi, S.-W., Katoch, A., Sun, G.-J., and Kim, S. S. (2013). Synthesis and gas sensing performance of $\mathrm{ZnO}-\mathrm{SnO}_{2}$ nanofiber-nanowire stem-branch heterostructure. Sensor. Actuat. B Chem. 181, 787-794. doi: 10.1016/j.snb.2013.02.010

Cui, G., Zhang, M., and Zou, G. (2013). Resonant tunneling modulation in quasi-2D $\mathrm{Cu}_{2} \mathrm{O} / \mathrm{SnO}_{2}$ p-n horizontal-multi-layer heterostructure for room temperature $\mathrm{H}_{2} \mathrm{~S}$ sensor application. Sci. Rep. 3:1250. doi: 10.1038/srep01250

Fang, G. J., Liu, Z. L., Liu, C. Q., and Yao, K. L. (2000). Room temperature $\mathrm{H}_{2} \mathrm{~S}$ sensing properties and mechanism of $\mathrm{CeO}_{2}-\mathrm{SnO}_{2}$ sol-gel thin films. Sensor. Actuat. B-Chem. 66, 46-48. doi: 10.1016/S0925-4005(99)00467-0

Hamrouni, A., Moussa, N., Parrino, F., Di Paola, A., Houas, A., and Palmisano, L. (2014). Sol-gel synthesis and photocatalytic activity of ZnO-SnO ${ }_{2}$ nanocomposites. J. Mol. Catal. A Chem. 390, 133-141. doi: 10.1016/j.molcata.2014.03.018

Hao, D., Zhu, J. H., Jiang, J., Ding, R. M., Feng, Y. M., Wei, G. M., et al. (2012). Preparation and gas-sensing property of ultra-fine $\mathrm{NiO} / \mathrm{SnO} 2$ nano-particles. RSC Adv. 2:10324-10329. doi: 10.1039/C2RA21121A

Hong, C., Zhou, Q., Lu, Z., Umar, A., Kumar, R., Wei, Z., et al. (2017). Ag-doped $\mathrm{ZnO}$ nanoellipsoids based highly sensitive gas sensor. Mater. Exp. 7, 380-388. doi: 10.1166/mex.2017.1388

Jiang, Z., Zhao, R., Sun, B., Nie, G., Ji, H., Lei, J., et al. (2016). Highly sensitive acetone sensor based on Eu-doped $\mathrm{SnO}_{2}$ electrospun nanofibers. Ceram. Int. 42, 15881-15888. doi: 10.1016/j.ceramint.2016.07.060

Kim, J.-H., Lee, J.-H., Mirzaei, A., Kim, H. W., and Kim, S. S. (2017). Optimization and gas sensing mechanism of $\mathrm{n}-\mathrm{SnO}_{2}-\mathrm{p}-\mathrm{Co}_{3} \mathrm{O}_{4}$ composite nanofibers. Sensor. Actuat. B-Chem. 248, 500-511. doi: 10.1016/j.snb.2017.04.029

Kolhe, P. S., Koinkar, P. M., Maiti, N., and Sonawane, K. M. (2017). Synthesis of Ag doped $\mathrm{SnO}_{2}$ thin films for the evaluation of $\mathrm{H}_{2} \mathrm{~S}$ gas sensing properties. Phys. $B$ Condensed Matter. 524, 90-96. doi: 10.1016/j.physb.2017.07.056

Kolhe, P. S., Shinde, A. B., Kulkarni, S. G., Maiti, N., Koinkar, P. M., and Sonawane, K. M. (2018). Gas sensing performance of $\mathrm{Al}$ doped $\mathrm{ZnO}$ thin revised the manuscript with input from all authors. All authors read and approved the manuscript.

\section{ACKNOWLEDGMENTS}

This work has been supported in part by the National Natural Science Foundation of China (No. 51507144), the China Postdoctoral Science Foundation Project (Nos. 2015M580771, 2016T90832), the Chongqing Science and Technology Commission (CSTC) (No. cstc2016jcyjA0400) and the project of China Scholarship Council (CSC).

film for $\mathrm{H}_{2} \mathrm{~S}$ detection. J. Alloy. Compd. 748, 6-11. doi: 10.1016/j.jallcom.2018. 03.123

Kong, J., Rui, Z., Ji, H., and Tong, Y. (2015). Facile synthesis of $\mathrm{ZnO} / \mathrm{SnO}_{2}$ hetero nanotubes with enhanced electrocatalytic property. Catal. Today 258, 75-82. doi: 10.1016/j.cattod.2015.04.011

Li, L., Fan, X. P., Zhou, Y. Y., Tang, N., Zou, Z. L., Liu, M. Z., et al. (2017). Research on technology of online gas chromatograph for $\mathrm{SF}_{6}$ decomposition products. IOP Conf. Ser. Mater. Sci. Eng. 274, 012-038. doi: $10.1088 / 1757-899 X / 274 / 1 / 012038$

Li, T., Zeng, W., Long, H., and Wang, Z. (2016). Nanosheet-assembled hierarchical $\mathrm{SnO}_{2}$ nanostructures for efficient gas-sensing applications. Sensor. Actuat. B-Chem. 231, 120-128. doi: 10.1016/j.snb.2016.03.003

Li, T. M., Zeng, W., and Wang, Z. C. (2015). Quasi-one-dimensional metal-oxidebased heterostructural gas-sensing materials: a review. Sensor. Actuat. B-Chem. 221, 1570-1585. doi: 10.1016/j.snb.2015.08.003

Li, W. Q., Ma, S. Y., Li, Y. F., Yang, G. J., Mao, Y. Z., Luo, J., et al. (2015). Enhanced ethanol sensing performance of hollow $\mathrm{ZnO}-\mathrm{SnO} 2$ core-shell nanofibers. Sensor. Actuat. B Chem. 221, 392-402. doi: 10.1016/j.snb.2015. 01.090

Liu, H. C., Zhou, Q., Zhang, Q. Y., Hong, C. X., Xu, L. N., Jin, L. F., et al. (2017). Synthesis, characterization and enhanced sensing properties of a $\mathrm{NiO} / \mathrm{ZnO}$ p-n junctions sensor for the $\mathrm{SF}_{6}$ decomposition byproducts $\mathrm{SO}_{2}, \mathrm{SO}_{2} \mathrm{~F}_{2}$, and $\mathrm{SOF}_{2}$. Sensors 17:913. doi: 10.3390/s17040913

Liu, J., Guo, W., Qu, F., Feng, C., Li, C., Zhu, L., et al. (2014). V-doped $\operatorname{In}_{2} \mathrm{O}_{3}$ nanofibers for $\mathrm{H}_{2} \mathrm{~S}$ detection at low temperature. Ceram. Int. 40, 6685-6689. doi: 10.1016/j.ceramint.2013.11.129

Long, H. W., Zeng, W., Wang, H., Qian, M. M., Liang, Y. H., and Wang, Z. C. (2018). Self-Assembled biomolecular 1D nanostructures for aqueous sodiumion battery. Adv. Sci. 5:1700634. doi: 10.1002/advs.201700634

Lu, Z., Zhou, Q., Xu, L., Gui, Y., Zhao, Z., Tang, C., et al. (2018). Synthesis and characterization of highly sensitive hydrogen $(\mathrm{H} 2)$ sensing device based on $\mathrm{Ag}$ doped SnO2 nanospheres. Materials 11:E492. doi: 10.3390/ma110 40492

Ma, G., Zou, R., Jiang, L., Zhang, Z., Xue, Y., Yu, L., et al. (2012). Phasecontrolled synthesis and gas-sensing properties of zinc stannate $\left(\mathrm{ZnSnO}_{3}\right.$ and $\mathrm{Zn}_{2} \mathrm{SnO}_{4}$ ) faceted solid and hollow microcrystals. CrystEngComm 14 2172-2179. doi: 10.1039/c2ce06272k

Miller, D. R., Akbar, S. A., and Morris, P. A. (2014). Nanoscale metal oxide-based heterojunctions for gas sensing: a review. Sensor. Actuat. B Chem. 204, 250-272. doi: 10.1016/j.snb.2014.07.074

Moon, S., Vuong, N. M., Lee, D., Kim, D., Lee, H., Kim, D., et al. (2016). $\mathrm{Co}_{3} \mathrm{O}_{4}-$ SWCNT composites for $\mathrm{H}_{2} \mathrm{~S}$ gas sensor application. Sensor. Actuat. B Chem. 222, 166-172. doi: 10.1016/j.snb.2015.08.072

Munasinghe Arachchige, H. M. M., Zappa, D., Poli, N., Gunawardhana, N., and Comini, E. (2018). Gold functionalized $\mathrm{MoO}_{3}$ nanoflakes for gas sensing applications. Sensor. Actuat. B Chem. 269, 331-339. doi: $10.1016 / j . s n b .2018 .04 .124$

Nan, C., Li, Y. X., Deng, D. Y., Xu, L.,Xing, X. X., Xiao, X. C., et al. (2017). Acetone sensing performances based on nanoporous $\mathrm{TiO}_{2}$ synthesized by a facile hydrothermal method. Sensor. Actuat. B Chem. 238, 491-500. doi: 10.1016/j.snb.2016.07.094 
Park, J. Y., Kim, H. H., Rana, D., Jamwal, D., and Katoch, A. (2017). Surface-areacontrolled synthesis of porous $\mathrm{TiO}_{2}$ thin films for gas-sensing applications. Nanotechnology 28:095502. doi: 10.1088/1361-6528/aa5836

Park, S., Park, S., Jung, J., Hong, T., Lee, S., Kim, H. W., et al. (2014). $\mathrm{H}_{2} \mathrm{~S}$ gas sensing properties of $\mathrm{CuO}$-functionalized $\mathrm{WO}_{3}$ nanowires. Ceram. Int. 40, 11051-11056. doi: 10.1016/j.ceramint.2014.03.120

Qi, Q., Wang, P.-P., Zhao, J., Feng, L.-L., Zhou, L.-J., Xuan, R.-F., et al. (2014). $\mathrm{SnO}_{2}$ nanoparticle-coated $\mathrm{In}_{2} \mathrm{O}_{3}$ nanofibers with improved NH3 sensing properties. Sensor. Actuat. B Chem. 194, 440-446. doi: 10.1016/j.snb.2013.12.115

Qu, Z., Fu, Y., Yu, B., Deng, P., Xing, L., and Xue, X. (2016). High and fast $\mathrm{H}_{2} \mathrm{~S}$ response of $\mathrm{NiO} / \mathrm{ZnO}$ nanowire nanogenerator as a self-powered gas sensor. Sensor. Actuat. B Chem. 222, 78-86. doi: 10.1016/j.snb.2015.08.058

Shahabuddin, M., Umar, A., Tomar, M., and Gupta, V. (2017). Custom designed metal anchored $\mathrm{SnO}_{2}$ sensor for $\mathrm{H}_{2}$ detection. Int. J. Hydrogen Energ. 42, 4597-4609. doi: 10.1016/j.ijhydene.2016.12.054

Sun, G.-J., Kheel, H., Lee, J. K., Choi, S., Lee, S., and Lee, C. (2016). $\mathrm{H}_{2}$ S gas sensing properties of $\mathrm{Fe}_{2} \mathrm{O}_{3}$ nanoparticle-decorated $\mathrm{NiO}$ nanoplate sensors. Surf. Coat. Tech. 307, 1088-1095. doi: 10.1016/j.surfcoat.2016.06.066

Tomer, V. K., and Duhan, S. (2016). Ordered mesoporous Ag-doped $\mathrm{TiO}_{2} / \mathrm{SnO}_{2}$ nanocomposite based highly sensitive and selective VOC sensors. J. Mater. Chem. A 4, 1033-1043. doi: 10.1039/C5TA08336B

Tsai, W.-T. (2007). The decomposition products of sulfur hexafluoride $\left(\mathrm{SF}_{6}\right)$ : reviews of environmental and health risk analysis. J. Fluorine Chem. 128, 1345-1352. doi: 10.1016/j.jfluchem.2007.06.008

Wang, C., Zeng, W., and Chen, T. (2017). Facile synthesis of thin nanosheet assembled flower-like $\mathrm{NiO}-\mathrm{ZnO}$ composite and its ethanol-sensing performance. J. Mater. Sci. 28, 222-227. doi: 10.1007/s10854-016-5514-1

Wang, Y., Duan, G., Zhu, Y., Zhang, H., Xu, Z., Dai, Z., et al. (2016). Room temperature $\mathrm{H}_{2} \mathrm{~S}$ gas sensing properties of $\mathrm{In}_{2} \mathrm{O}_{3}$ micro/nanostructured porous thin film and hydrolyzation-induced enhanced sensing mechanism. Sensor. Actuat. B Chem. 228, 74-84. doi: 10.1016/j.snb.2016.01.002

Wei, S. H., Wang, S. M., Zhang, Y., and Zhou, M. H. (2014). Different morphologies of $\mathrm{ZnO}$ and their ethanol sensing property. Sensor. Actuat. B Chem. 192, 480-487. doi: 10.1016/j.snb.2013.11.034

Xu, L., Chen, N., Han, B. Q., Xiao, X. C., Chen, G., Djerdj, L., et al. (2015). Nanoparticle cluster gas sensor: Pt activated $\mathrm{SnO}_{2}$ nanoparticles for $\mathrm{NH}_{3}$ detection with ultrahigh sensitivity. Nanoscale 36, 14872-14880. doi: $10.1039 / C 5 N R 03585 F$

Yang, F., Zhu, J., Zou, X., Pang, X., Yang, R., Chen, S., et al. (2018). Threedimensional $\mathrm{TiO}_{2} / \mathrm{SiO}_{2}$ composite aerogel films via atomic layer deposition with enhanced $\mathrm{H}_{2} \mathrm{~S}$ gas sensing performance. Ceram. Int. 44, 1078-1085. doi: 10.1016/j.ceramint.2017.10.052

Zeng, W., Liu, T. M., and Wang, Z. C. (2012). Enhanced gas sensing properties by $\mathrm{SnO}_{2}$ nanosphere functionalized $\mathrm{TiO}_{2}$ nanobelts. J. Mater. Chem. 22, 3544-3548. doi: 10.1039/c2jm15017d

Zhang, H., Zeng, W., Zhang, Y., Li, Y. Q., Miao, B., Chen, W. G., et al. (2014). Synthesis and gas sensing properties of novel $\mathrm{SnO}_{2}$ nanorods. J. Mater. Sci. Mater. El. 25, 5006-5012. doi: 10.1007/s10854-014-2264-9

Zhang, Q. Y., Zhou, Q., Yin, X. T., Liu, H. C., Xu, L. N., Tan, W. M., et al. (2017). The effect of PMMA pore-forming on hydrogen sensing properties of porous $\mathrm{SnO}_{2}$ thick film sensor. Sci. Adv. Mater. 9, 1350-1355. doi: 10.1166/sam.2017.3111

Zhang, W., Xie, C., Zhang, G., Zhang, J., Zhang, S., and Zeng, D. (2017). Porous $\mathrm{LaFeO}_{3} / \mathrm{SnO}_{2}$ nanocomposite film for $\mathrm{CO}_{2}$ detection with high sensitivity. Mater. Chem. Phys. 186, 228-236. doi: 10.1016/j.matchemphys.2016.10.048

Zhang, X., Cui, H., Gui, Y., and Tang, J. (2017). Mechanism and application of carbon nanotube sensors in $\mathrm{SF}_{6}$ decomposed production detection: a review. Nanoscale Res. Lett. 12:177. doi: 10.1186/s11671-017-1945-8

Zhang, X., Gui, Y., and Dong, X. (2016). Preparation and application of $\mathrm{TiO}_{2}$ nanotube array gas Sensor for $\mathrm{SF}_{6}$-insulated equipment detection: a review. Nanoscale Res. Lett. 11:302. doi: 10.1186/s11671-016-1516-4
Zhang, Y., Wang, J., Wei, H., Hao, J., Mu, J., Cao, P., et al. (2016). Hydrothermal synthesis of hierarchical mesoporous $\mathrm{NiO}$ nanourchins and their supercapacitor application. Mater. Lett. 162, 67-70. doi: 10.1016/j.matlet.2015.09.123

Zhang, Y., Zeng, W., and Li, Y. (2018). The hydrothermal synthesis of 3D hierarchical porous $\mathrm{MoS}_{2}$ microspheres assembled by nanosheets with excellent gas sensing properties. J. Alloy. Compd. 749, 355-362. doi: 10.1016/j.jallcom.2018.03.307

Zhang, Y. X., Zeng, W., Ye, H., and Li, Y. Q. (2018). Enhanced carbon monoxide sensing properties of $\mathrm{TiO}_{2}$ with exposed (001) facet: a combined first-principle and experimental study. Appl. Surf. Sci. 442, 507-516. doi: 10.1016/j.apsusc.2018.02.036

Zhao, Y., Li, X., Dong, L., Yan, B., Shan, H., Li, D., et al. (2015). Electrospun $\mathrm{SnO}_{2}-\mathrm{ZnO}$ nanofibers with improved electrochemical performance as anode materials for lithium-ion batteries. Int. J. Hydrogen Energ. 40, 14338-14344. doi: 10.1016/j.ijhydene.2015.06.054

Zhou, Q., Chen, W., Xu, L., Kumar, R., Gui, Y., Zhao, Z., et al. (2018a). Highly sensitive carbon monoxide (CO) gas sensors based on $\mathrm{Ni}$ and $\mathrm{Zn}$ doped $\mathrm{SnO}_{2}$ nanomaterials. Ceram. Int. 44, 4392-4399. doi: 10.1016/j.ceramint.2017. 12.038

Zhou, Q., Chen, W., Xu, L., and Peng, S. (2013). Hydrothermal synthesis of various hierarchical $\mathrm{ZnO}$ nanostructures and their methane sensing properties. Sensors 13, 6171-6182. doi: 10.3390/s130506171

Zhou, Q., Lu, Z., Wei, Z., Xu, L., Gui, Y., and Chen, W. (2018b). Hydrothermal synthesis of hierarchical ultrathin $\mathrm{NiO}$ nanoflakes for high-performance $\mathrm{CH}_{4}$ sensing. Front. Chem. 6:194. doi: 10.3389/fchem.2018.00194

Zhou, Q., Tang, C., Zhu, S. P., and Chen, W. G. (2015). NiO doped $\mathrm{SnO}_{2}$ p-n heterojunction microspheres: preparation, characterisation and CO sensing properties. Mater. Technol. 30, 349-355. doi: 10.1179/17535557 $15 Y .0000000010$

Zhou, Q., Umar, A., Sodki, E., Amine, A., Xu, L. N., Gui, Y. G., et al. (2018c), Fabrication and characterization of highly sensitive and selective sensors based on porous NiO nanodisks. Sensor. Actuat. B. Chem. 259, 604-615. doi: 10.1016/j.snb.2017.12.050

Zhou, Q., Xu, L., Umar, A., Chen, W., and Kumar, R. (2018d). Pt nanoparticles decorated $\mathrm{SnO}_{2}$ nanoneedles for efficient $\mathrm{CO}$ gas sensing applications. Sensor. Actuat. B-Chem. 256, 656-664. doi: 10.1016/j.snb.2017.09.206

Zhu, L., Li, Y. Q., and Zeng, W. (2017). Enhanced ethanol sensing and mechanism of $\mathrm{Cr}$-doped $\mathrm{ZnO}$ nanorods: experimental and computational study. Ceram. Int. 43, 14873-14879. doi: 10.1016/j.ceramint.2017.08.003

Zhu, L., Zeng, W., Ye, H., and Li, Y. Q. (2018). Volatile organic compound sensing based on coral rock-like ZnO. Mater. Res. Bull. 100, 259-264. doi: 10.1016/j.materresbull.2017.12.043

Zou, C. W., Wang, J., and Xie, W. (2016). Synthesis and enhanced $\mathrm{NO}_{2}$ gas sensing properties of $\mathrm{ZnO}$ nanorods/ $/ \mathrm{TiO}_{2}$ nanoparticles heterojunction composites. J. Colloid Interf. Sci. 478, 22-28. doi: 10.1016/j.jcis.2016. 05.061

Zuo, Z. J., Wang, L., Liu, Y.-J., and Huang, W. (2013). The effect of CuO-ZnO$\mathrm{Al}_{2} \mathrm{O}_{3}$ catalyst structure on the ethanol synthesis from syngas. Catal. Commun. 34, 69-72. doi: 10.1016/j.catcom.2013.01.008

Conflict of Interest Statement: The authors declare that the research was conducted in the absence of any commercial or financial relationships that could be construed as a potential conflict of interest.

Copyright () $2018 \mathrm{Lu}, \mathrm{Zhou}$, Wang, Wei, Xu and Gui. This is an open-access article distributed under the terms of the Creative Commons Attribution License (CC BY). The use, distribution or reproduction in other forums is permitted, provided the original author(s) and the copyright owner(s) are credited and that the original publication in this journal is cited, in accordance with accepted academic practice. No use, distribution or reproduction is permitted which does not comply with these terms. 